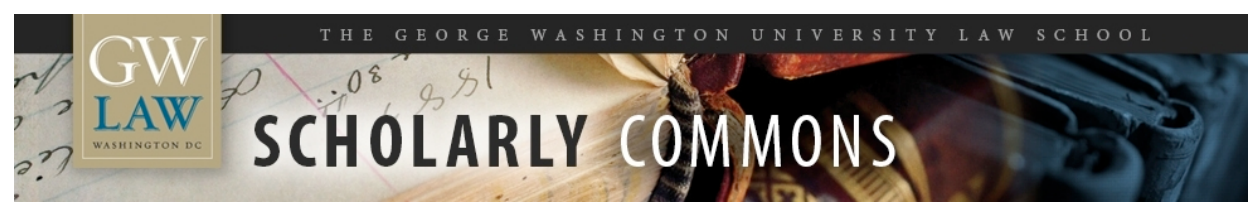

\title{
The Expulsion of Aliens and Other Topics: The Sixty-Fourth Session of the International Law Commission
}

\author{
Sean D. Murphy \\ George Washington University Law School, smurphy@law.gwu.edu
}

Follow this and additional works at: https://scholarship.law.gwu.edu/faculty_publications

Part of the Law Commons

\section{Recommended Citation}

Sean D. Murphy, The Expulsion of Aliens and Other Topics: The Sixty-Fourth Session of the International Law Commission, 107 Am. J. Int'I L. 164 (2013).

This Article is brought to you for free and open access by the Faculty Scholarship at Scholarly Commons. It has been accepted for inclusion in GW Law Faculty Publications \& Other Works by an authorized administrator of Scholarly Commons. For more information, please contact spagel@law.gwu.edu. 


\section{CURRENT DEVELOPMENTS}

The Expulsion of Aliens And Other Topics: The SiXty-Fourth Session of the INTERNATIONAL LAW COMMISSION

[forthcoming in 107 AMERICAN JOURNAL OF INTERNATIONAL LAW (2013)]

$$
\text { By Sean D. Murphy }
$$

The International Law Commission held its sixty-fourth session in Geneva from May 7 to June 1, and from July 2 to August 3, 2012, under the chairmanship of Lucius Caflisch. ${ }^{1}$ The session marked the first year of a new quinquennium (2012-2016), with the Commission having completed its work during the prior quinquennium on four major topics: transboundary aquifers; reservations to treaties; responsibility of international organizations; and effects of armed conflict on treaties. ${ }^{2}$

The central topic under discussion during the sixty-fourth session concerned the expulsion of aliens, which led to the adoption on first reading of thirty-two articles,

\footnotetext{
${ }^{1}$ See Report of the International Law Commission on the Work of Its Sixty-Fourth Session, UN GAOR, 64th Sess., Supp. No. 10, at 1-2, UN Doc. A/67/10 (2006) [hereinafter 2012 Report].

${ }^{2}$ See Donald McRae, The Work of the International Law Commission, 2007-2011, 106 AM. J. INT’L L. 322, 325-31 (2012).
} 
together with commentaries, regarding a State's power to remove non-nationals coercively from its territory. Work proceeded on the other topics already on the ILC's agenda and two new topics were added to that agenda: the provisional application of treaties and customary international law.

\section{EXPULSION OF ALIENS}

The issue of expulsion of aliens is an important and controversial issue in the national politics of many nations. In 2004, the ILC included this topic on its agenda and appointed Maurice Kamto (Cameroon) as ILC special rapporteur. Kamto has submitted eight reports analyzing the law in this area and proposing a series of draft articles that partly codify and partly progressively develop the law. After several years of development of those articles through discussions in the ILC's plenary sessions and in its drafting committee, thirty-two articles were adopted on "first reading" during the sixty-fourth session, together with commentaries. ${ }^{3}$ The draft articles recognize a general right of states to expel aliens from their territory, but only "in accordance with the present draft articles and other applicable rules of international law, in particular those relating to human rights." 4

\footnotetext{
${ }^{3}$ Draft Articles on the Expulsion of Aliens, in 2012 Report, supra note 1, at 18, para. 46 [hereinafter Draft Articles on the Expulsion of Aliens].

${ }^{4}$ Id., Art. 3.
} 
The draft articles define "alien" as a person who does not have the nationality of the state engaging in the expulsion, ${ }^{5}$ thus covering both persons with a foreign nationality and stateless persons. The alien must be "present in the territory" of the state," ${ }^{\prime 6}$ which excludes aliens who enter an embassy, consulate, military base, or other facility of the state located abroad, as well as aliens stopped on vess els located outside territorial waters. Such aliens include persons who are displaced across a border, ${ }^{7}$ perhaps due to a famine or an internal armed conflict. By way of example, the some 200,000 persons who have fled from Syria into Jordan over the past two years ${ }^{8}$ would be covered by these articles, whether or not they are classified as refugees or they entered Jordan legally.

"Expulsion" is defined as "a formal act, or conduct consisting of an action or omission, attributable to a State by which an alien is compelled to leave the territory of that State...." At the same time, "expulsion" does not include extradition of a person to another state, does not include surrender of a person to an international tribunal, and does not include the "non-admission" of a person to a state, unless that person is a

\footnotetext{
${ }^{5}$ Id., Art. 2(b).

6 Id., Art. 1(1).

${ }^{7} 2012$ Report, supra note 1, at 20.
}

${ }^{8}$ See Aida Alami, Syrians Join Relief Efforts for Countrymen in Jordan, N.Y. TIMES, Sept. 13, 2012, at A1.

${ }^{9}$ Draft Articles on the Expulsion of Aliens, supra note 3, Art. 2(a). 
"refugee." 10 This last carve-out means that a person who is stopped at the border of a state or at a port of entry (such as an airport) and who is identified as not able to enter the country lawfully, may be sent back by immigration authorities to the place from whence they came without being regarded as "expelled," even though the person was physically present (temporarily) in the state, unless they are a "refugee" within the meaning of relevant international treaties. ${ }^{11}$ The draft articles also do not apply to persons who enjoy privileges and immunities under international law, such as diplomats or military personnel covered by a status of forces agreement. ${ }^{12}$ Such persons may be expelled by the state in accordance with whatever rules apply for the regime through which they receive their privileges and immunities.

Though the draft articles do not cover situations of non-admission, they do cover aliens who are unlawfully present in the state, ${ }^{13}$ whether by entering the state legally but then becoming illegal (perhaps by overstaying the term of a visa), or by entering the state illegally and undetected. ${ }^{14}$ The protections accorded to illegal aliens are almost identical to those accorded to legal aliens, such as those who have been resident in the

${ }^{10} I d$. Such exclusions are also likely intended to cover transfers of prisoners due to law enforcement agreements, for purposes of testifying or serving a sentence in another country.

${ }^{11} 2012$ Report, supra note 1 , at 21.

${ }^{12}$ Draft Articles on the Expulsion of Aliens, supra note 3, Art. 1(2).

${ }^{13}$ Id., Art. 1(1).

142012 Report, supra note 1 , at $19 \& 21$. 
state for many years. By granting to illegal aliens largely the same protections as are accorded to legal aliens, the draft articles move beyond the national laws of many states and the European Union, ${ }^{15}$ and beyond provisions on expulsion contained in widelyadhered-to human rights instruments, ${ }^{16}$ which differentiate between the two groups.

As noted above, a state may expel the alien, but only "in accordance with the present draft articles and other applicable rules of international law, in particular those relating to human rights." ${ }^{17}$ That language suggests that a state must comply with both obligations identified in the draft articles and in "other applicable rules," such as multilateral treaties to which it is a party. Left unsaid in the draft articles is what should

${ }^{15}$ Expulsion of Aliens: Memorandum by the Secretariat of the International Law Commission, U.N. Doc. A/CN.4/565, at 98-101 (2006) [hereinfter Secretariat 2006 Memorandum].

16 For examples of treaties that accord protections only to aliens lawfully present in the state, see U.N. Convention Relating to the Status of Refugees, July 28, 1951, art 32, 19 U.S.T. 6259, 189 U.N.T.S. 150; International Covenant on Civil and Political Rights, Dec. 16, 1966, art. 13, 999 U.N.T.S. 171 (ICCPR); 1955 European Convention on Establishment, art. 3; American Convention on Human Rights, Nov. 22, 1969, art. 22(6),1144 U.N.T.S. 123, 9 I.L.M. 673, as amended by protocols of Nov. 14, 1988, 28 I.L.M. 156, and June 8, 1990, 29 I.L.M. 1447; African Charter on Human and People's Rights, June 27, 1981, art. 12(4), 21 I.L.M. 58; League of Arab States Charter on Human Rights, May 22, 2004, art. 26, reprinted in 12 InT'L HuM. RTS. ReP. 893 (2005).

${ }^{17}$ Draft Articles on the Expulsion of Aliens, supra note 3, Art. 3. 
happen if the draft articles conflict with "other applicable rules." For example, several major human rights instruments set forth obligations relating to expulsion, ${ }^{18}$ but also allow for derogation from those obligations in a time of emergency. ${ }^{19}$ The draft articles, by contrast, contain no provision allowing for derogation in time of emergency, so it appears possible that, in certain situations, the draft articles might require the state to respect rights relating to expulsion, while the "other applicable rules" would not. One technique for sorting out such conflicts might be to choose the norm-set most favorable to the alien, although this would mean setting aside some very fundamental rules in widely-adhered-to treaties. Yet the current ILC commentary to this article seems to indicate otherwise, by stating that "other applicable rules" includes rules on derogation in times of emergency, implying that, in the event of a conflict, even other norms less protective of the alien should apply. Greater clarity may be necessary on this point; as noted above, several international treaties that address expulsion accord protections only to persons "legally present" in a state's territory, while denying such protections to persons not legally present. If those "other applicable rules" govern in the event of conflict, then coverage by these draft articles of illegal aliens may be largely illusory.

A state wishing to expel an alien who falls within the scope of the draft articles must do so "only in pursuance of a decision reached in accordance with law," 20 and that decision must be based upon a ground for expulsion that is provided for in the national

18 See, e.g., ICCPR, Art. 13.

19 See, e.g., id., Art. 4.

${ }^{20}$ Draft Articles on the Expulsion of Aliens, supra note 3, Art. 4. 
law, which "shall be assessed in good faith and reasonably." ${ }^{21}$ Thus, if the national law allows for expulsion of an alien because he procured his admission improperly, such as by marriage fraud, or because he has committed a serious crime, then the alien may be expelled.

Once an alien is identified as subject to expulsion, the state must accord to him or her a range of procedural protections, including the right to receive notice of the decision to expel, to challenge the decision before a competent authority, and to be represented before that authority, including with the assistance of an interpreter if necessary. ${ }^{22}$ These procedural protections, however, can be deviated from if the alien has been unlawfully present in the territory for less than six months, ${ }^{23}$ a somewhat arbitrary deadline selected out of a recognition that many states do not accord such procedural rights when expelling illegal aliens. Moreover, only appeals lodged by aliens lawfully present in the state have a "suspensive effect" on the expulsion until the appeal is resolved. ${ }^{24}$ All aliens, however, if detained must be kept separate from the normal prison population, the detention cannot be punitive or for an unrestricted duration, the detention must be reviewed at regular intervals, and it must normally end if the expulsion cannot be carried out. ${ }^{25}$

\footnotetext{
${ }^{21} I d$., Art. 5.

${ }^{22}$ Id., Art. 26(1).

${ }^{23} I d$., Art. 26(4).

${ }^{24}$ Id., Art. 27.

${ }^{25}$ Id., Art. 19.
} 
Various types of expulsions are flatly prohibited. The state cannot expel a refugee (or a person who has applied for refugee status) or a stateless person except on grounds of national security or public order. ${ }^{26}$ The state cannot "make its national an alien, by deprivation of nationality, for the sole purpose of expelling him or her." ${ }^{27}$ The state cannot collectively expel aliens as a group, though it may expel all enemy aliens in time of armed conflict, when permitted under the jus in bello. ${ }^{28}$ The state cannot engage in "disguised expulsion," by which is meant committing acts or omissions with the intent of indirectly forcing the alien to depart. ${ }^{29}$ (This form of expulsion is often

${ }^{26} I d .$, Arts. $6 \& 7$.

${ }^{27} I d$., Art. 9. This is the one draft article that regulates a state's treatment of its own nationals and, indeed, is a rule about nationality law, not about expulsion as such. A reformulation more oriented toward expulsion might prohibit a state from expelling an alien whose nationality it has withdrawn solely for the purpose of expulsion.

${ }^{28}$ Id., Art. 10; see Secretariat 2006 Memorandum, supra note 15 at 546, para. 951 ("A State may be entitled to expel all enemy aliens in the context of an armed conflict under international law, even though this may result in the expulsion of a large number of individuals.”). On mass expulsions generally, see JEAN-MARIE HENCKAERTS, MASS EXPULSION IN MODERN INTERNATIONAL LAW AND PRACTICE (1995).

${ }^{29}$ Draft Articles on the Expulsion of Aliens, supra note 3, Art. 11. The "intent" element of this definition is important. If a state fires an alien from a government position, and due to the loss of that job the alien has no economic choice but to return to his own 
referred to in English as "constructive expulsion," but that term does not translate well into other languages.) The state cannot expel an alien for the purpose of confiscating his or her assets ${ }^{30}$ or to circumvent an ongoing extradition procedure. ${ }^{31}$

Even if expulsion is permissible, it must be undertaken with humanity, with respect for the alien's dignity, ${ }^{32}$ without discrimination based on various categories (such as race and sex), ${ }^{33}$ and with regard for "vulnerable persons" (such as pregnant women). ${ }^{34}$ Various human rights are asserted as applying to aliens who are subject to expulsion, including the right to life, the right not to be tortured, and the right to family life. ${ }^{35}$ The state must first pursue a "voluntary departure" of the alien but, if forced expulsion is necessary, the state must give the alien "a reasonable period of time to prepare for his or her departure, having regard to all the circumstances." 36

state, the alien has not been "expelled" unless it can be shown that the firing was undertaken with the intention of provoking the departure.

${ }^{30} I d$., Art. 12.

${ }^{31}$ Id., Art. 13.

${ }^{32}$ Id., Art. 14.

${ }^{33}$ Id., Art. 15.

${ }^{34}$ Id., Art. 16.

${ }^{35}$ Id., Arts. 17, 18, \& 20.

${ }^{36} I d .$, Art. 21. 
As for the destination of the expellee, the draft articles provide that the alien "shall be expelled to his or her State of nationality or any other State that has the obligation to receive the alien under international law, or to any State willing to accept him or her at the request of the expelling State or, where appropriate, of the alien in question." ${ }^{37}$ If no such state can be identified, then the alien can be expelled "to any State where he or she has a right of entry or stay or, where applicable, to the State from where he or she has entered the expelling State." 38 An alien cannot be expelled to a state where his or her life or freedom would be threatened on grounds such as race or sex, ${ }^{39}$ or where there are substantial grounds for believing that he or she would be subject to torture or cruel, inhuman or degrading treatment or punishment. ${ }^{40} \mathrm{~A}$ state that does not apply the death penalty may not expel an alien to another state "where the life of the

${ }^{37}$ Id., Art. 22(1).

${ }^{38}$ Id., Art. 22(2).

${ }^{39}$ Id., Art. 23.

${ }^{40}$ Id., Art. 24. The non-refoulement provision of the Convention Against Torture and Other Cruel, Inhuman or Degrading Treatment or Punishment, Dec. 10, 1984, art. 3(1), S. Treaty Doc. No. 100-20 (1988), 1465 U.N.T.S. 85, is limited to the sending of a person to another State where he would be in danger of being subjected to torture, so the draft articles go further in adding "or to cruel, inhuman or de grading treatment or punishment." 
alien would be threatened with the death penalty," unless it obtains assurance that the death penalty will not be imposed or carried out. ${ }^{41}$

If an alien is unlawfully expelled, he or she has the right to be readmitted to the state "if it is established by a competent authority that the expulsion was unlawful, save where his or her return constitutes a threat to national security or public order, or where the alien otherwise no longer fulfils the conditions for admission under the law of the expelling State." ${ }^{\prime 2}$

The thirty-two articles, together with commentaries, are not yet final. Having undergone a "first reading," they are now being sent to governments for comments and observations by no later than January 1, 2014. After that, the Commission will proceed to revise and improve the articles and commentary during the "second reading," with the intention of their completion and adoption in 2015.

\section{OTHER TOPICS}

Obligation to extradite or prosecute (aut dedere aut judicare)

In 2005, the Commission decided to include this topic in its program of work and to appoint Zdzislaw Galicki (Poland) as Special Rapporteur. Ultimately, a working group was also formed to assist the Special Rapporteur, who produced four reports (in

\footnotetext{
${ }^{41}$ Draft Articles on the Expulsion of Aliens, supra note 3, Art. 23(2).

${ }^{42}$ Id., Art. 29.
} 
2006, 2007, 2008, and 2011). With the start of the new quinquennium in 2012, the Commission decided not to appoint a new special rapporteur to replace Galicki, who was no longer a member of the Commission. Instead, the Commission established a working group chaired by Kriangsak Kittichaisaree (Thailand), for the purpose of considering the best way forward. After several meetings, the group asked the chair to prepare a working paper for the sixty-fifth session "reviewing the various perspectives in relation to the topic in light of the judgment" of the International Court on July 20, 2012 in Questions Relating to the Obligation to Prosecute or Extradite. ${ }^{43}$

While the general subject of of aut dedere aut judicare is an important one for international law, it is not clear how best the Commission might proceed. One possibility would be for a general study of the complex web of treaties that contains aut dedere/aut judicare obligations, but that task has already been accomplished by a study of the Commission's secretariat in 2010, which analyzed sixty-one multilateral treaties at global and regional level. ${ }^{44}$ Another possibility would be for the Commission to address a specific problem or difficulty that States are confronting in fulfilling those treaty obligations, but to date no chronic problem regarding treaty language or treaty

43 See 2012 Report, supra note 1, at 120; Questions Relating to the Obligation to Prosecute or Extradite, I.C.J. Judgment, July 20, 2012, at <http://www.icjcij.org/docket/files/144/17064.pdf>.

${ }^{44}$ Survey of multilateral conventions which may be of relevance for the work of the International Law Commission on the topic "The obligation to extradite or prosecute (aut dedere aut judicare)," Study by the Secretariat of the International Law Commission, U.N. Doc. A/CN.4/630 (June 18, 2010). 
interpretation has been identified. There are, of course, specific issues of implementation that will arise in certain circumstances, where two States disagree about the application of discrete facts to their treaty obligations (as occurred in the Belgium/Senegal case), but those are not issues the Commission can resolve.

Alternatively, the Commission might address whether there exists (or does not exist) as a matter of customary international law an aut dedere/aut judicare obligation with respect to certain types of crimes. In 1996, the Commission identified in its Draft Code of Crimes Against the Peace and Security of Mankind a possible aut dederelaut judicare obligation with respect to genocide, crimes against humanity, and war crimes. ${ }^{45}$ At that time, such an obligation was recognized by the Commission as constituting progressive development of international law, which would only bind those States that adopted and adhered to such a code (which has not happened to date). At present, it may be difficult to establish widespread and uniform state practice in support of a customary aut dederelaut judicare obligation; even for the "core crimes" of

\footnotetext{
${ }^{45}$ Draft Code of Crimes Against the Peace and Security of Mankind, Report of the International Law Commission on the Work of Its Forty-Eighth Session, UN GAOR, 51st Sess., Supp. No. 10, at 9, UN Doc. A/51/10 (1996). Article 9 of the Draft Code provides that "the State Party in the territory of which an individual alleged to have committed a crime set out in article $17,18,19$ or 20 is found shall extradite or prosecute that individual." Those articles deal respectively with the crime of genocide, crimes against humanity, crimes against United Nations and associated personnel, and war crimes.
} 
international law, "many states [have] failed to define all of these crimes under international law as crimes under national law." ${ }^{46}$

The International Court's judgment in the Belgium/Senegal case did not address whether there exists a customary aut dederelaut judicare obligation, for jurisdictional reasons. Yet Judge Abraham asserted that there was no customary norm binding upon Senegal to prosecute former President Habré in its courts, whether for torture, war crimes, crimes against humanity, or genocide. ${ }^{47}$ Judge Abraham especially cast doubt on the existence of a customary norm when the crime at issue was committed outside the territory of the state seeking extradition, and neither the alleged offender nor the victims were nationals of that state ${ }^{48}$ Though Belgium apparently presented to the Court data concerning fifty-one states that exercised certain forms of universal jurisdiction, ${ }^{49}$ Judge Abraham regarded such data as inadequate to support a customary norm, ${ }^{50}$ asserting that his own country of France's exercise of universal jurisdiction was either treaty-based or

\footnotetext{
${ }^{46}$ AmNesty InTERnAtional, Universal JuRisdiction: A Preliminary SurVey of LegisLation AROUND THE WorLD, at 1 (2011).
}

${ }^{47}$ Questions Relating to the Obligation to Prosecute or Extradite, supra note 42, Separate Opinion of Judge Abraham, at para. 21.

${ }^{48} I d .$, paras. $31-33$.

${ }^{49} I d$., para. 34.

${ }^{50} I d .$, paras. $36-38$. 
done as a matter of sovereign discretion, not due to opinio juris. ${ }^{51}$ Judge ad hoc Sur concurred that a customary aut dedere/aut judicare obligation did not exist and further indicated that the Court's unwillingness to reach the issue on the merits was driven, in part, by a concern that the Court not stifle the emergence of such a norm in the future by declaring its non-existence today. ${ }^{52}$

These and other matters concerning this topic remain to be discussed within the Commission during the upcoming sixty-five session, for the purpose of deciding whether and, if so, how to move forward with this topic.

Protection of persons in the event of disasters

As special rapporteur for this topic, Eduardo Valencia-Ospina (Colombia) has completed five reports analyzing the applicable international law in circumstances of disaster, defined as "a calamitous event or series of events resulting in widespread loss of life, great human suffering and distress, or large-scale material or environmental damage, thereby seriously disrupting the functioning of society." 53 The draft articles

${ }^{51} I d .$, para. 39.

${ }^{52}$ Questions Relating to the Obligation to Prosecute or Extradite, supra note 42,

Dissenting Opinion of ad hoc Judge Sur, at para. 21.

${ }^{53}$ Draft Articles on the Protection of Persons in the Event of Disasters, Art. 3, in 2012 Report, supra note 1, at 90, para. 81 [hereinafter Draft Articles on the Protection of Persons in the Event of Disasters]. 
seek to set forth rules applicable to the state in which the disaster occurred and to those states or non-state actors that are in a position to provide assistance. As has been noted elsewhere, the topic is somewhat unusual in that it is unclear whether existing state practice reflects legal rights or obligations, and there is "little by way of relevant treaty provisions or judicial or arbitral decisions" to guide the Commission. ${ }^{54}$

To date, eleven draft articles have been provisionally adopted on matters such as the duty and forms of cooperation and offers of assistance. Key articles provisionally adopted so far ${ }^{55}$ provide that the "affected State, by virtue of its sovereignty, has the duty to ensure the protection of persons and provision of disaster relief and assistance on its territory" (Art. 9), and "the duty to seek assistance from among other States, the United Nations, other competent intergovernmental organizations and relevant nongovernmental organizations, as appropriate" (Art. 10). At the same time, the "provision of external assistance requires the consent of the affected State," although that consent "shall not be withheld arbitrarily" (Art. 11). In crafting such articles, the Commission is seeking to balance the responsibility of a State toward its nationals in a time of disaster with its sovereign right to determine whether and how assistance from other States shall occur.

During the sixty-fourth session, the Commission's drafting committee considered and adopted further articles elaborating on the duty to cooperate, the

\footnotetext{
${ }^{54}$ McRae, supra note 2, at 336.
}

${ }^{55}$ Draft Articles on the Protection of Persons in the Event of Disasters, supra note 53, Arts. 9-11. 
conditions that may be placed on assistance, and termination of assistance. ValenciaOspina will prepare two further reports focusing on the pre-disaster phase and on the protection of relief personnel and miscellaneous issues, with the intention of completing a first reading of the draft articles by the end of this quinquennium (i.e., by 2016).

Immunity of state officials from foreign criminal jurisdiction

As indicated by the title, this topic is not concerned with a state official's immunity from the jurisdiction of international criminal tribunals, is not concerned with the official's immunity from the jurisdiction of the state of his or her own nationality, and is not concerned with the official's immunity from civil jurisdiction. Rather, the topic concerns immunity of a state official from the national criminal jurisdiction of another state.

The topic was included in the ILC's agenda in 2007 and Roman A. Kolodkin (Russia) was appointed Special Rapporteur. Thereafter, he submitted three reports which were discussed by the Commission in 2008 and 2011. Those reports canvassed in considerable depth state practice on the subject, as well as important decisions by the International Court of Justice. For example, in the 2008 case on Certain Questions of Mutual Assistance in Criminal Matters, the Court asserted that a claim of immunity for a government official is, in essence, a claim of immunity for the state, from which the official benefits. ${ }^{56}$ For this reason, a state may waive the official's immunity; it is an

\footnotetext{
${ }^{56}$ Certain Questions of Mutual Assistance in Criminal Matters (Djib. v. Fr.), 2008 I.C.J 177, ๆ 188 (June 4).
} 
immunity that, at its heart, is meant to protect the state and not the official. In the 2002 Arrest Warrant judgment, the Court identified heads of state, heads of government, and foreign ministers, along with other holders of high-ranking office, as enjoying full immunity from criminal jurisdiction while in office, without exception. ${ }^{57}$ Such immunity (typically referred to as immunity rationae personae) only applies during the official's time in office, and may be distinguished from the immunity held by state officials more generally for their "official" acts, while in office and thereafter (typically referred to as immunity ratione materiae).

Based on his analysis of state practice and international jurisprudence, Kolodkin concluded that "[o]n the whole, the immunity of a State official, like that of the State itself, from foreign jurisdiction is the general rule, and its absence in a particular case is the exception to this rule." ${ }^{58}$ Further, "the absence of immunity ... has to be proven, and not ... the existence of immunity." ${ }^{, 59}$ Any exception to such immunity can be found only if it has developed into a norm of customary international law, ${ }^{60}$ which Kolodkin found had not occurred. Indeed, in his view the "various rationales for exceptions to the

${ }^{57}$ Arrest Warrant of 11 April 2000 (Dem. Rep. Congo v. Belgium), 2002 I.C.J. 3, ๆף 51 58 (Feb. 14); see also Armed Activities (Dem. Rep. Congo v. Rwanda), 2006 I.C.J. 6, ๆ 46 (Feb. 3).

${ }^{58}$ Second report on immunity of State officials from foreign criminal jurisdiction, Roman Anatolevich Kolodkin, Special Rapporteur, U.N. Doc. A/CN.4/631, ๆ 94(a) (June 10, 2010).

${ }^{59} I d . \rrbracket 18$. 
immunity of State officials from foreign criminal jurisdiction are not sufficiently convincing," 61 including "the proposition that very grave human rights violations are criminalized and prohibited by the peremptory norms of general international law," 62 and "the idea that a customary norm of international law has developed, under which such immunity does not operate where an official has committed a grave crime under international law."63 Kolodkin did not propose any draft articles codifying or progressively developing the law on this topic and did not stand for reelection at the end of the quinquennium.

At its sixty-fourth session, the Commission appointed as Special Rapporteur for the topic Conception Escobar Hernandez (Spain) - the first woman to serve as a special rapporteur in the history of the Commission. Escobar Hernández prepared and the Commission discussed a preliminary report, which signaled that she intends to build upon Kolodkin's work, but with a fresh look, and for the purpose of formulating draft articles. Escobar Hernández intends to submit a first report for consideration at the ILC's sixty-fifth session in 2013, to be followed by further reports, all with the intention of completing a series of draft articles on first reading by the end of the current quinquennium. To assist in its work, the Commission is asking states to provide information on their national law and practice on the following questions: (1) does the distinction between immunity ratione personae and immunity ratione materiae result in

${ }^{61} I d \cdot$ ๆ $94(\mathrm{n})$

${ }^{62} I d . \uparrow 63$.

63 Id. ๆ 68. 
different legal consequences and, if so, how are they treated differently?; and (2) what criteria are used in identifying the persons covered by immunity ratione personae?"64

In its 2012 judgment on Jurisdictional Immunities of the State, the International Court found that "customary international law does not treat a State's entitlement to immunity as dependent upon the gravity of the act of which it is accused or the peremptory nature of the rule which it is alleged to have violated." ${ }^{65}$ Although in that instance the Court made a point of saying that it was only assessing state immunity, not immunity of officials, ${ }^{66}$ there are various ways in which the Court's basic reasoning nevertheless may be relevant to the ILC's work on official immunity. First, the Court said it was problematic to deny state immunity based solely on an allegation of a serious international crime, because doing so invites a litigant to craft the allegations skillfully solely to negate the immunity. ${ }^{67}$ Second, even an allegation that the state's acts violated a norm of jus cogens was not seen as altering a norm on state immunity from national jurisdiction, since the two norms are addressing different things. ${ }^{68}$ (The jus cogens rule may establish that the act was substantively unlawful, but that does not mean that the

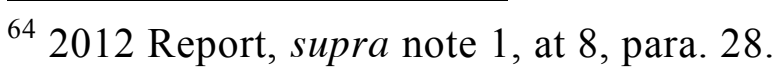

65 Jurisdictional Immunities of the State (Germany v. Italy), 2012 I.C.J. I 84 (date), available online at $<$ www.icj-cij.org $>$.

${ }^{66}$ Id. 91.

${ }^{67}$ Id. $\ 82$.

${ }^{68}$ Id. ๆ 92-97. 
illegal act, as a procedural matter, may be litigated in a national court.) ${ }^{69}$ Third, stripping away state immunity was not appropriate simply to ensure accountability; there was no evidence that the right to state immunity was preconditioned on the availability of a venue other than national courts for pursuing redress. ${ }^{70}$ Fourth, in terms of methodology, the Court appears to have assumed the existence of immunity and then looked for an exception based on settled state practice. ${ }^{71}$ Such reasoning might be applied to immunities of officials as well.

${ }^{69}$ If such reasoning is relevant to the immunity of officials, it may refute arguments advanced by some judges in national and international proceedings. See, e.g., R. v. Bow St. Metro. Stipendiary Magistrate, ex parte Pinochet Ugarte, [1999] UKHL 17, [2000] 1 A.C. 147, 278 (H.L.) (opinion of Lord Millett in the House of Lords third major decision in the Pinochet case); Italy v. Lozano, Case No. 31171/2008; ILDC 1805 (IT 2008) (July 24, 2008) (decision by Italian Court of Cassation); Al-Adsani v. United Kingdom, 2001-XI Eur. Ct. H.R. 79, 103 (2001) (view of dissenting judges before the European Court of Human Rights).

${ }^{70}$ Jurisdictional Immunities of the State, $\mid \uparrow 98-104$; see Arrest Warrant of 11 April 2000, supra note 57, Joint Separate Opinion of Judges Higgins, Kooijmans and Buergenthal, at 979 .

${ }^{71}$ Jurisdictional Immunities of the State, 985. 
These matters, as well as new decisions at the national level concerning immunity of foreign officials from criminal jurisdiction, will continue to be discussed within the Commission during this quinquennium.

\section{Provisional application of treaties}

The Commission also decided at the sixty-fourth session to add to its agenda a new topic on the provisional application of treaties and to appoint Juan Manuel GomezRobledo (Mexico) as Special Rapporteur. ${ }^{72}$ This topic concerns the application of the rights and obligations of a treaty prior to the point where the treaty enters into force, pursuant to an agreement between the parties that the treaty shall be applied provisionally. Gomez-Robledo chaired informal consultations on the topic as a means of obtaining guidance from ILC members for use in preparing his first report, which will be considered at the sixty-fifth session in 2013.

Although this topic has not received much attention in the academic literature, and is not a common feature of treaty practice, provisional application nevertheless can arise in some very significant multilateral agreements, such as trade and commodity agreements, and significant bilateral agreements, including arms control and maritime agreements. For example, the United States maritime boundaries with Russia in the Arctic Ocean, Bering Sea, and northern Pacific Ocean, and with Cuba, ${ }^{73}$ operate provisionally. Likewise, when President Obama and Russian President Medvedev signed the "New START Treaty" on April 8, 2010, they also signed a protocol which

\footnotetext{
722012 Report, supra note 1 , at 105.
} 
provided that " $[\mathrm{u}] \mathrm{ntil}$ entry into force of the Treaty, the provisions of the Treaty and this Protocol, listed in this Part, shall apply provisionally from the date of signature of the Treaty."74

Article 25 of the Vienna Convention on the Law of Treaties (VCLT) addresses provisional application of treaties in two short paragraphs. ${ }^{75}$ Nevertheless, several questions remain outstanding that might answered through the Commission's work on this topic, including what exactly is mean by "provisional application." The VCLT does not actually define "provisional" or "application," or what it means for a treaty to be "applied provisionally." The Restatement (Third) of the Foreign Relations Law of the United States identifies at least three different contexts where the term "provisional application" has been used, perhaps not always correctly. ${ }^{76}$ The manner in which provisional application operates for a multilateral treaty might be clarified, given that some states may have only voted to adopt the treaty, while others may have signed the treaty, while still others may have failed to sign but have announced an intention to

${ }^{74}$ See Treaty on Measures for the Further Reduction and Limitation of Strategic Offensive Arms, U.S.-Russ., Apr. 8, 2010, Treaty Doc. No. 111-5, at Protocol, pt. 8 (2010); see generally Congressional Research Service, The New START Treaty: Central Limits and Key Provisions, CRS Rep. R41219 (Apr. 21, 2011).

${ }^{75}$ Vienna Convention on the Law of Treaties, art. 25, 1155 U.N.T.S. 331, 8 I.L.M. 679 (1969).

${ }^{76}$ Restatement (ThiRd) of the Foreign Relations LAW of the United States, $§$ 312, cmt. d (1987). 
accede. Rules might also be developed on the processes of opting into or opting out of provisional application, on the date when provisional application takes effect, and on whether some parts of the treaty do not apply on the provisional basis if they seem to presuppose actual entry into force of the agreement. ${ }^{77}$ The relationship with national law also poses important issues; for example, Article 45(1) of the Energy Charter Treaty provides that provisional application occurs "to the extent that such provisional application is not inconsistent with the State's constitution, laws or regulations."78 Arguably, such a clause refers broadly to the ability of a state to apply provisionally a treaty without normal ratification procedures, but it might also be said to require consistency between particular substantive clauses of the treaty and the state's national law relating to those clauses. ${ }^{79}$ The date on which provisional application terminates

77 See Kardassopoulos v. Georgia, ICSID Case No. ARB/05/18, Decision on Jurisdiction, paras. 220-21 (July 6, 2007).

${ }^{78}$ Energy Charter Treaty, Dec. 17, 1994, art. 45(1), 2080 U.N.T.S. 95, 34 I.L.M. 360

(1995). A similar issue arises in the Implementing Agreement on Part XI of the LOSC, which calls for provisionally application by states "in accordance with their national or internal laws and regulations." See Agreement Relating to the Implementation of Part XI of the United Nations Convention on the Law of the Sea of 10 December 1982, July 28, 1994, art. 7(2), S. Treaty Doc. No. 103-39, at 263 (1994), 1836 U.N.T.S. 41.

${ }^{79}$ Kardassopoulos, supra note 77, at paras. 225-46; see Yukos Universal Limited v. Russian Federation, Interim Award on Jurisdiction and Admissibility, para. 302 (Nov. 30, 2009), at <http://www.encharter.org/fileadmin/user_upload/document/ Yukos_interim_award.pdf $>$. ("In the Tribunal's opinion, by signing the ECT, the Russian Federation agreed that the Treaty as a whole would be applied provisionally 
might also be clarified. VCLT Art. 25(2) says it is terminated when the state notifies other states that it intends not to become a party to the treaty, yet it presumably also ends when the state becomes a party to the treaty in relation to other states that have also become parties, while continuing in relation to those states that have not. ${ }^{80}$ The Commission might also confirm that an agreement to apply a treaty provisionally creates a legally-binding obligation, as opposed to a political commitment, the breach of which does not engage the legal responsibility of the state. The view is often expressed in state practice that such an agreement is legally binding, ${ }^{81}$ and arbitral decisions ${ }^{82}$ and leading commentators ${ }^{83}$ appear to be in accord.

pending its entry into force unless the principle of provisional application itself were inconsistent 'with its constitution, laws or regulations."”)

${ }^{80}$ It should be noted that the ILC's original drafts of what became Article 25(2) allowed for the possibility of withdrawing from the provisional regime without necessarily indicating an intent not to join the treaty. That possibility was dropped at the Diplomatic Conference.

${ }^{81}$ See, e.g., 1980 Digest of United States Practice in InTERnAtional Law, Ch. 5, Sec. 1 (Department of State response to a Senate inquiry asserting that "such a provision itself constitutes a binding international agreement ").

${ }^{82}$ Kardassopoulos v. Georgia, supra note 77, at para. 209 ("The Tribunal cannot ... accept Respondent's argument that provisional application is only aspirational in character."); id., at para. 210 ("the implication is that it would be applied on the same basis as would in due course result from the [Energy Charter Treaty]'s (definitive) entry into force, and as if it had already done so."); Yukos Universal Limited, supra note 79, 
Formation and evidence of customary international law

The Commission decided at the sixty-fourth session to add to its agenda a new topic on the formation and evidence of customary international law and to appoint Michael Wood (United Kingdom) as Special Rapporteur. As indicated by the title, the topic is not aimed at canvassing the substantive rules of customary international law but, rather, at the "secondary" rules regarding how such law is formed, and the types of evidence relevant in determining whether the requirements set forth in those secondary rules have been met. The objectives of the topic generally are twofold: to provide greater certainty as to the process of customary international law formation, so as to encourage greater acceptance of such law; and to provide practical guidance to judges and lawyers called upon to apply this law, including within national legal systems.

at para. 313 ("[T]he fundamental reason why States agree to apply a treaty provisionally ... [is] in order to assume obligations immediately pending the completion of various internal procedures necessary to have the treaty enter into force.”); id., at para. 314 ("Allowing a State to modulate (or, as the case may be, eliminate) the obligation of provisional application, depending on the content of its internal law in relation to the specific provisions found in the Treaty, would undermine the principle that provisional application of a treaty creates binding obligations.")

${ }^{83}$ See, e.g., The Vienna Conventions on the Law of Treaties: A Commentary, Volume 1, at 652 (Olivier Corten \& Pierre Klein, eds., 2011) ("provided that it is valid, the agreement on provisional application produces the same legal effects as any international agreement and as such, it is subject to the rule pacta sunt servanda."). 
One existing restatement of law in this area is the Statement of Principles Applicable to the Formation of General Customary International Law, adopted in 2000 by the International Law Association. ${ }^{84}$ That restatement contains thirty-three principles, with associated commentary, and may be a prototype for the Commission's end-product (Wood has indicated that he does not favor the development of draft articles). Two important issues that will no doubt feature in the Commission's work are: the degree to which resolutions of international organizations can serve as evidence of the existence of a customary norm; and the circumstances under which a widely accepted multilateral treaty may be said to codify or crystalize a customary norm, such that it non-parties to the treaty are also bound to the norm.

The Commission engaged in an initial debate on the topic, based on a Note prepared by Wood, ${ }^{85}$ as a means of providing guidance to him for preparing his first report, which will be considered at the sixty-fifth session in 2013. Further, the Commission's secretariat will prepare a study of the previous work of the Commission relevant to this topic. The Commission is also asking governments to provide

84 International Law Association, Statement of Principles Applicable to the Formation of General Customary International Law, with Commentary, Res. 16/2000 (July 29, 2000), in International Law Association, Report of the Sixty-ninth Conference, London 39 (2000); see M.H. Mendelson, The Formation of Customary International Law, 272 R.A.C.D.I. 155 (1998).

${ }^{85}$ Error! Main Document Only.Formation and evidence of customary international law, Note by Michael Wood, Special Rapporteur. UN Doc. A/CN.4/653 (2012). 
information on their state practice relating to the formation of customary international law and the types of evidence suitable for establishing such law in a given situation. ${ }^{86}$

\section{Treaties over time}

The Commission reconstituted its study group on this topic for the sixty-fourth session, which completed its consideration of the second report by its chairman, Georg Nolte (Germany). The second report focused on the jurisprudence of "special regimes" (such as the World Trade Organization Dispute Resolution Body or regional human rights courts) addressing the use of subsequent agreements or subsequent practice when interpreting a treaty. Further, the second report contained a series of preliminary conclusions, which have been reformulated based on discussions within the study group. The study group also considered a third report by the chairman focused on the use of subsequent agreement or practice outside the judicial or quasi-judicial context, such as in the practice of states or international organizations. ${ }^{87}$

In light of the progress to date, the Commission has decided to pursue this topic in the future under the title "subsequent agreements and subsequent practice in relation to the interpretation of treaties," with Nolte as special rapporteur. It is expected that he will develop further reports integrating and extending the work to date on this topic, with finalization of a series of draft conclusions and commentary by the end the current quinquennium.

\footnotetext{
${ }^{86} 2012$ Report, supra note 1 , at 8, para. 29.

${ }^{87}$ The three study group reports are all on file with the author.
} 


\section{Most-favored-nation clause}

During the sixty-fourth session, the Commission reconstituted its study group on this topic, under the chairmanship of Donald McRae (Canada). Generally, the objective of this topic is to identify areas where the Commission might assist in minimizing the fragmentation of international law as it relates to interpretation of most-favored-nation (MFN) clauses, especially by disparate arbitral tribunals convened pursuant to investment treaties.

The principal focus of the discussion at the sixty-fourth session were the factors that influence investment tribunals when interpreting MFN clauses, with particular attention as to whether MFN clauses can and do encompass provisions on dispute resolution (in other words, whether a more favorable dispute resolution provision in another investment treaty may be invoked by the investor). ${ }^{88}$ In that regard, the Study Group tentatively concluded that whether an MFN provision was capable of applying to a dispute resolution provision was a matter of treaty interpretation, one that could only be answered in the circumstances of each particular treaty, and that states were free to

${ }^{88} 2012$ Report, supra note 1, at 127-32; compare Emilio Agustin Maffezini v. Spain, ICSID Case No. ARB 97/7 (Jan. 25, 2000) (decision on jurisdiction), with Plama v. Bulgaria, ICSID Case No. ARB/03/24 (Feb. 8, 2005) (decision on jurisdiction) and Impregilo S.p.A. v. Argentine Republic (Italy-Argentina BIT), ICSID Case No. ARB/07/17 (June 21, 2011) (concurring and dissenting opinion of Professor Brigitte Stern). 
expressly include or exclude such application. Where the issue was not expressly addressed, the Study Group identified various potentially relevant factors for further study, such as whether it matters if the rule being imported relates to the tribunal's jurisdiction as compared with the admissibility of the claim.

The Working Group is not planning to revise or supplement the draft articles on MFN clauses that were completed in 1978. Rather, McRae intends in 2013 to present a draft final report of the working group analyzing and contextualizing the case law in this area, and possibility developing guidelines or model clauses for addressing problem areas. The Working Group or its Chairman may then be in a position to complete a final report by 2015 .

III. Future Topics AND Procedural Matters

At present the Commission has seven topics on its long-term work program, which might be moved to its active agenda: ownership \& protection of wrecks beyond the limits of national maritime jurisdiction (added in 1996); jurisdictional immunity of international organizations (2006); protection of personal data in trans-border flow of information (2006); extraterritorial jurisdiction (2006); fair and equitable treatment standard in international investment law (2011); protection of the environment in relation to armed conflicts (2011); and protection of the atmosphere (2011). The last two of these topics were discussed at some length during the sixty-fourth session, but no decision was reached on whether to move forward with them. 